\title{
EC+ A TOOL FOR CREATING COMMUNICATION \\ OPPORTUNITIES AT SCHOOL.
}

\author{
Marina Calleja Reina \\ Universidad de Málaga
}




\section{Erasmus Plus project $\mathrm{EC}+$}

- https://ecplusproject.uma.es
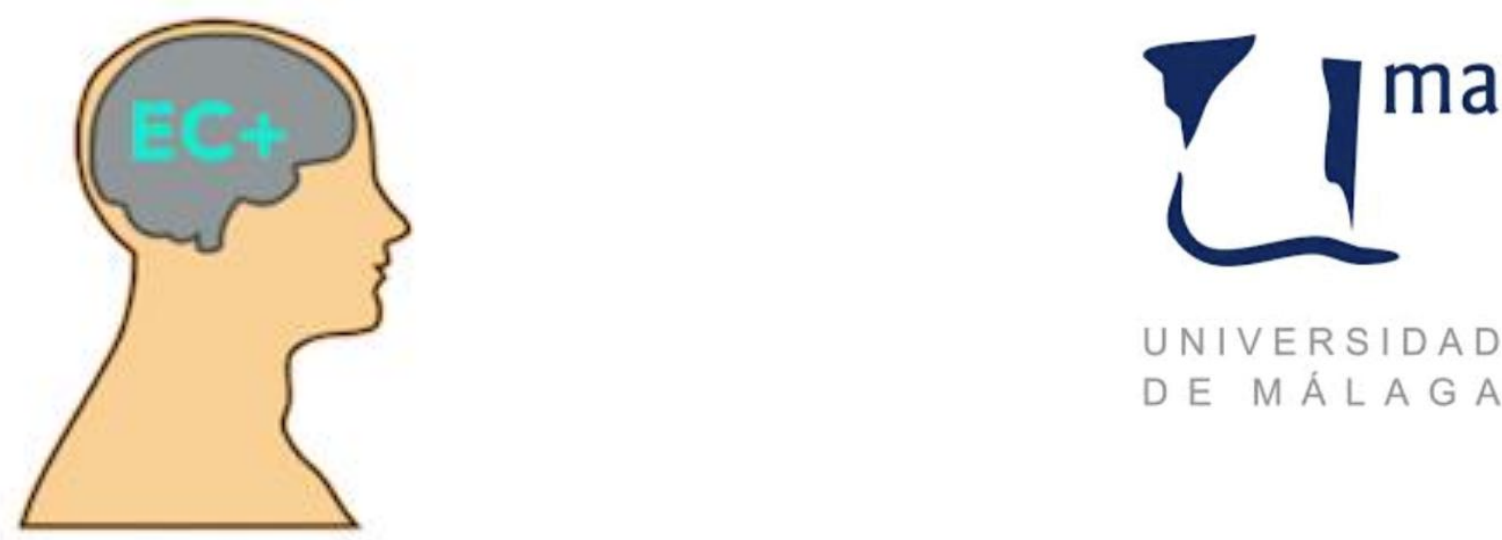

UNIVERSIDAD

DE MÁLA G A

EC+: Enhancing communication: research to improve communication for people with special needs and development of ICT resources and tools. 


\section{Intellectual disability is characterized by}

-Significant limitations in intellectual functioning and in adaptive behavior, expressed in the conceptual, social and practical adaptive skills.

-Intellectual disability emerges before the age of 18 (AAIDD or American Association on Intellectual and Developmental Dissabilities). 


\section{Communication is}

$>$ A Right Human (Universal Declaration of

Human Rights of the United Nations, 1994).

$>$ Essential for all aspects of life

$>$ Necessary to ensure the quality of life.

$>$ Essential for learning processes. 


\section{Effective communication allows people}

- Express their thoughts, opinions and personality

-Make request and receive information

-Build relationships

- Take their own decisions

- Express primary needs

-Express rejection 


\section{How do we communicate?}

- Speech

- Writing

- Touch

- Eye contact

- Voice tone

- Signs

- Gestures

- Body expression

- Pantomime

- Vocalizations 


\section{complex communication needs (CCN)}

- People who can not carry out communicative exchanges effectively through conventional communication channels, show complex communication needs (CCN)

- For some people, NCCs are temporary, while for others they are permanent. 
$>\mathrm{CCN}$ may be caused by significant speech, language and / or cognitive damage.

$>$ The principal characteristic of a subject with NCC is that he can not carry out communicative exchanges by conventional ways. 
$>$ The area of clinical practice that supports and satisfies these communication needs is the Augmentative and Alternative Communication (AAC)

$>$ Through the use of symbols, aids, strategies and techniques, success and communicative effectiveness are improved. 


\section{$\mathrm{SID}+\mathrm{CCN}$}

- The educational intervention becomes extremely complex when occur Severe Intellectual Disability (SID) in conjunction with $\mathrm{CCN}$. Then we have to use the Augmentative and / or Alternative Communication Systems(CAA) (Romski y Sevcik, 2005). 


\section{EC+: Enhancing communication}

This research work has been carried out within the framework or the Erasmus Plus project EC+: Enhancing communication: research to improve communication for people with special needs and development of ICT resources and tools.

Reference number: 2015-1-ES01-KA203-015625 https://sites.google.com/site/ecplusproject/ 


\section{EC +: app for smartphones and tablets}

$\mathrm{EC}+$ is an AAC device of high technological level from the assumptions of multimodal communication. This application uses pictograms, manual signs, photographs and words 


\section{Users}

- SID and Partners Communication in several setting:

- Home

- Clinical

- School 


\section{Example of search by alphabetical order}

Án+ Abrigo




\section{multimodal presentation of words}

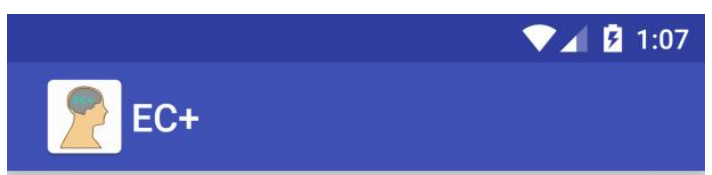

Manzana
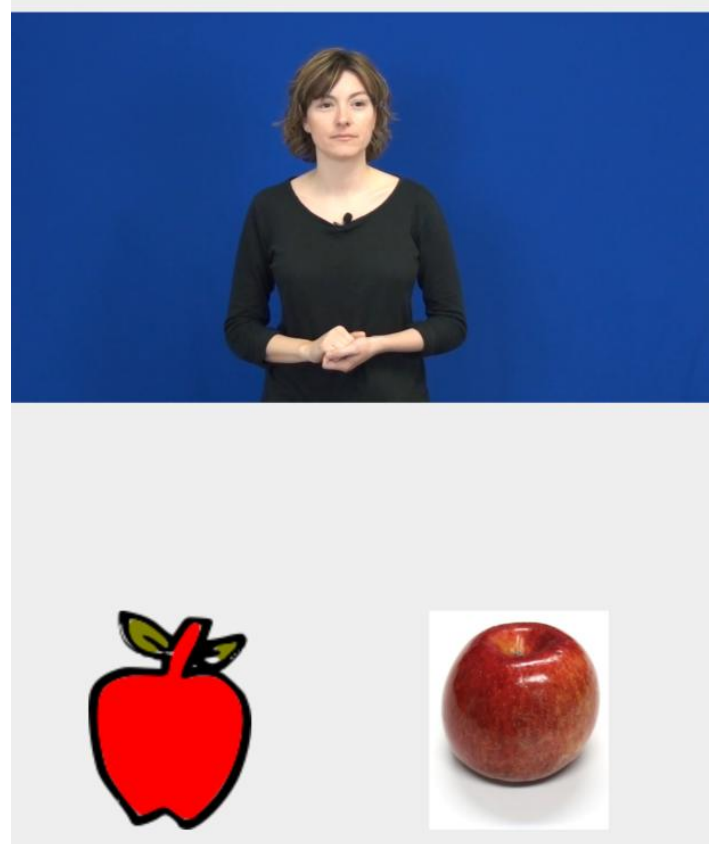
International Conference on Research in Education, Teaching and Learning

Paris, France| November 2-4, 2018

Medical guide of syndromes

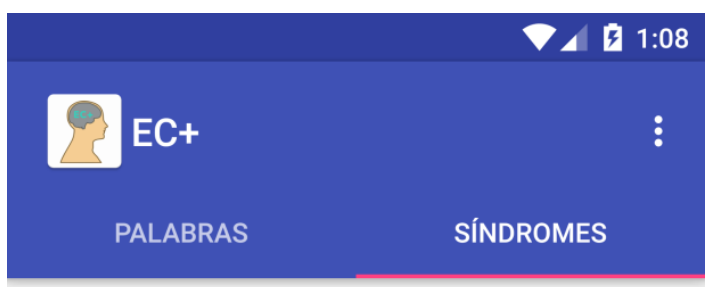

Angelman

Pitt Hopkins

Mowat Wilson

Phelan McDermid

Kleefstra

Clásico de Rett

Autismo severo

Microduplicación/microdeleción con

afectación grave del lenguaje

Parálisis cerebral tetraparesia distónica

West 


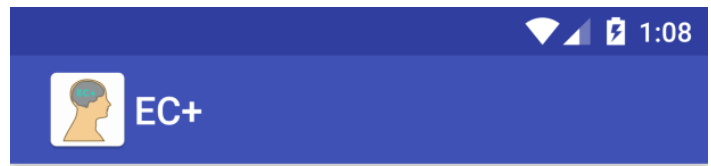

\section{Síndrome de Angelman}

\section{Características generales}

El Síndrome de Angelman (SA) se caracteriza clínicamente por rasgos físicos, alteraciones neurológicas y un perfil cognitivo y conductual muy específico. Incidencia de 1 por 15000 individuos.

\section{Causa}

Es un trastorno de base genética causado por una falta de expresión del gen UBE3A localizado en el cromosoma 15 de origen materno. La pérdida física o funcional puede tener cuatro orígenes distintos:

1. Deleción de 15q11-q13 de origen materno

2. Disomía uniparental de 15q11-q13 de origen paterno

3. Mutación de la impronta

4. Mutación del gen UBE3A.

Existe un quinto grupo de pacientes que presenta una clínica de SA en el que se desconoce la causa. 
- Muchas gracias por su atención

- Marina Calleja Reina

- Universidad de Málaga

- España

- Ec+ project

- marinac@uma.es 